\title{
Shape of Detonation Wave in Different Energetic Materials Based on Nitrocellulose and Nitroglycerine
}

\author{
Jovica Bogdanov ${ }^{1)}$ \\ Uroš Anđelić ${ }^{2)}$ \\ ZoranBajićc \\ Saša Brzić ${ }^{2)}$ \\ JovicaNešić ${ }^{2)}$
}

\begin{abstract}
The experimental research on shape of detonation wave was done for cylindrical explosive charges with 5 different energetic materials with nitrocellulose and nitroglycerine. Energetic materials were manufactured with the technology for production of ball propellants. Shape of detonation wave was determined using the method of measurement of detonation wave arrival time to a certain point in the charge. Measurement system was developed in the Military Technical Institute (VTI) in Belgrade and had 16 fibre optic cables, multi-channel optical signal detector and oscilloscope. Curvature of detonation wave was determined at two different distances from initiation point. Average radii of detonation waves were determined using the regression analysis of experimental data. Also, the change in detonation wave curvature was observed at different distances from the detonator.
\end{abstract}

Key words: detonation wave, energetic materials, nitrocellulose, nitroglycerine.

\section{List of abbreviations and acronyms}

AGD - average grain dimension;

AN - ammonium nitrate;

ANFO - ammonium nitrate with fuel oil;

$\mathrm{BC}-$ booster charge;

C(s) - solid carbon;

DBP - dibutylphthalate;

DPA - diphenylamine;

DW - detonation wave;

EDC - electric detonating cap;

EM - energetic material;

hum - humidity;

MP - measuring point;

$\mathrm{NC}$ - nitrocellulose;

NG - nitroglycerine;

FOH - fiber optic holder;

PETN - pentaerythritol tetranitrate, penthrite;

solv - solvent;

TNT - trinitrotoluene.

\section{Introduction}

$\mathrm{D}$ ETONATION can be considered as a stationary process where balance between parameters of process and external conditions is achieved. When process is disturbed, the changes of those values occur and new balance is achieved. The knowledge on detonation parameters can help to determine nature and characteristics of the process itself. In theoretical considerations there can be two distinctive behaviours of the detonation: ideal and non-ideal. Ideal detonation is considered when detonation parameters have values that correspond to Chapman-Jouguet condition of the system and can be explained using Zel'dovich-von NeumannDöring detonation model [1-2]. Non-ideal detonation can also be stable. The research on detonation in liquid energetic materials (EM) showed that process is self-sustained even during significant non-ideal behaviour [2]. Other research showed that detonation wave front can also have pulsating propagation [3].

Non-ideal detonation is found in heterogeneous charges with significant amount of inert or slow-reacting components [4-5]. Such EM are insensitive explosives, ANFO explosives, explosives with metal powders, etc. There were developed many models of non-ideal detonation [5-6].

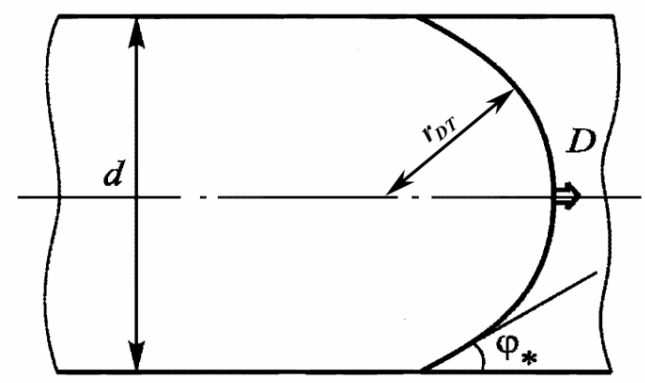

Figure 1. Schematic representation of curved detonation wave [1]

Theories on ideal detonation assume plain DW front. Curvature of detonation wave (DW) front is considered to be a consequence of non-ideal detonation. DW is planar when explosive charge diameter is many times larger than critical diameter of the EM inside it. Most models of non-ideal detonation are based on the Wood-Kirkwood theory on

\footnotetext{
1) Military Academy (VA), University of Defence, Generala Pavla Jurišića Šturma 33,11000 Belgrade, SERBIA

2) Military Technical Institute (VTI), Ratka Resanovića 1, 11132 Belgrade, SERBIA

Correspondence to: Jovica Bogdanov; e-mail: jovica.bogdanov@va.mod.gov.rs
} 
curvature of DW in cylindrical charges [7]. Curved DW which is propagating with detonation velocity $D$ inside explosive charge with diameter $d$ is represented in Fig.1 [1]. In reality, DW has a complex shape, but can be approximated with a part of a circle with radius $r_{D T}$.

Value $r_{D T}$ is an average radius of DW and is appropriate for determination of changes in DW curvature.

\section{Experiments}

Experimental measurements of DW curvature were done for explosive charges with five different energetic materials with nitrocellulose (NC) and nitroglycerine (NG), which can be used as propellants in small-arms or artillery ammunition. Considered propellants were produced in Chemical industry "Milan Blagojević", Lučani, Republic of Serbia (MBL). Compositions are listed in Table 1 [8].

Two propellants (SB-520 and SB-412) are used in ammunition for $7.62 \mathrm{~mm}$ assault rifles and $9 \mathrm{~mm}$ pistols and submachine guns, respectively. Other three propellants (DSB20, DSB-15 and DSB-10) were mixtures of single base and double-base propellants, produced using ball (spherical) propellant technology. Grains of these propellants were not flattened and have approximately spherical shape. Characteristics of propellants are listed in Tables 1 and 2.

Propellants were filled inside cylindrical explosive charges with $0.3 \mathrm{~mm}$ thick paper casings, bonded with $0.07 \mathrm{~mm}$ adhesive tape. Diameter of all charges $d_{\mathrm{EP}}$ was $50 \mathrm{~mm}$. There were two different charge lengths $l_{\mathrm{EP}}, 100$ and $185 \mathrm{~mm}$.

Table 1. Compositions of propellants

\begin{tabular}{|c|c|c|c|c|c|c|c|c|c|}
\hline \multirow{2}{*}{$\begin{array}{c}\text { Energetic } \\
\text { material }\end{array}$} & \multicolumn{9}{|c|}{ Content, mas. $\%$} \\
\hline & $\begin{array}{l}\text { nitrogenin } \\
\mathrm{NC}, \omega_{N}\end{array}$ & $\omega_{N C}$ & $\omega_{N G}$ & $\omega_{D P A}$ & $\omega_{D E P}$ & $\omega_{K N O_{3}}$ & $\omega_{C_{(s)}}$ & $\omega_{\text {solv }}$ & $\omega_{\mathrm{H}_{2} \mathrm{O}}$ \\
\hline SB-520 & \multirow{5}{*}{13.20} & 81.08 & 10.36 & 1.11 & 5.49 & 0.10 & 0.21 & 0.46 & 1.19 \\
\hline SB-412 & & 79.58 & 18.70 & 1.02 & & & 0.17 & & 0.53 \\
\hline DSB-20 & & 77.44 & 20.09 & 1.09 & & & 0.10 & 0.25 & 1.03 \\
\hline DSB-15 & & 82.45 & 15.07 & 1.12 & & & 0.10 & 0.23 & 1.03 \\
\hline DSB-10 & & 87.46 & 10.05 & 1.14 & & & 0.10 & 0.21 & 1.04 \\
\hline
\end{tabular}

Table 2. Main characteristics of energetic materials [8]

\begin{tabular}{|c|c|c|c|c||}
\hline \multirow{2}{*}{$\begin{array}{c}\text { Energetic } \\
\text { material }\end{array}$} & \multirow{2}{*}{ Grain shape } & Molar mass & $\begin{array}{c}\text { Heat poten- } \\
\text { tial }\end{array}$ & $\begin{array}{c}\text { Average grain dimen- } \\
\text { sion }\end{array}$ \\
\cline { 3 - 5 } & $M, \mathrm{gmol}^{-1}$ & $Q, \mathrm{~kJ}^{-\mathrm{kg}^{-1}}$ & $A G D, \mathrm{~mm}$ \\
\hline SB-520 & $\begin{array}{c}\text { flattened } \\
\text { sphere }\end{array}$ & 213.02 & 3651 & $0.4953 \div 0.5716$ \\
\hline SB-412 & $\begin{array}{c}\text { flattened } \\
\text { sphere }\end{array}$ & 241.79 & 4350 & $0.3429 \div 0.4191$ \\
\hline DSB-20 & sphere & 221.77 & 4668 & $0.4953 \div 0.5715$ \\
\hline DSB-15 & sphere & 224.68 & 4505 & $0.4953 \div 0.5715$ \\
\hline DSB-10 & sphere & 227.36 & 4342 & $0.4953 \div 0.5715$ \\
\hline
\end{tabular}

Charges were initiated using electric detonation caps (EDC) "EK-40-69" and spherical booster charges (BC) with 8 $\mathrm{g}$ of explosive consisted of $85 \%$ PETN and $15 \%$ polymer binder. Lower end of EDC were positioned in the centre of boosters. The boosters had $22 \mathrm{~mm}$ diameter and were placed to $10 \mathrm{~mm}$ depth into charges. Shape and dimensions of explosive charges are shown in Fig.2. Characteristics of explosive charges are listed in Table 3.

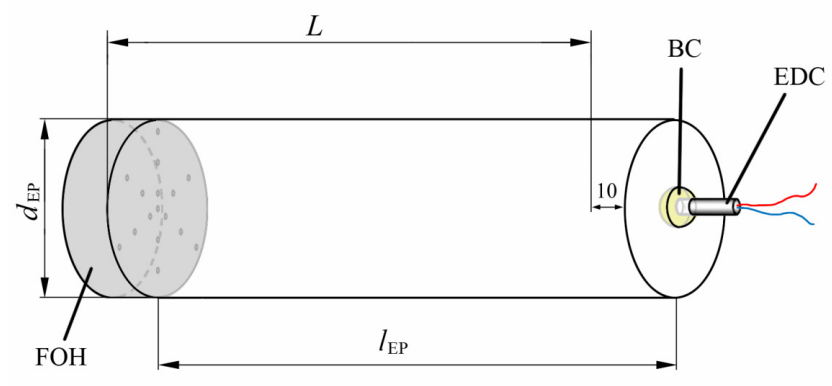

Figure 2. Experimental setup with charge dimensions

Shape of DW was experimentally determined by time of DW arrival to a certain point in the explosive charge. These moments can be recorded because of the intense light emission from the DW. Optic cables have the ability to transmit that light effect to optical transducers where they are transformed to electrical signals which could be recorded. Insulated single core fibre optic cables were used in this research (cable diameter $2.2 \mathrm{~mm}$, core diameter $1 \mathrm{~mm}$ ).

Measurement system used in this research was developed in the Military Technical Institute (VTI) in Belgrade. There were 16 fibre optic cables used inside an appropriate cylindrical fibre optic holder $(\mathrm{FOH})$ positioned on the surface opposite to the point of initiation, which is shown in Fig.2.

Table 3. Characteristics of explosive charges

\begin{tabular}{|c|c|c|c|c|c||}
\hline \hline \multirow{2}{*}{$\begin{array}{c}\text { Charge } \\
\text { No }\end{array}$} & \multirow{2}{*}{$\begin{array}{c}\text { Energetic } \\
\text { material }\end{array}$} & $\begin{array}{c}\text { Mass of } \\
\text { propellant }\end{array}$ & $\begin{array}{c}\text { Charge } \\
\text { length }\end{array}$ & $\begin{array}{c}\text { Charge } \\
\text { volume }\end{array}$ & $\begin{array}{c}\text { Charge } \\
\text { density }\end{array}$ \\
\cline { 3 - 3 } & & $\mathrm{m}_{\mathrm{SB}}, \mathrm{kg}$ & \multirow{2}{*}{$l_{\mathrm{EP}}, \mathrm{mm}$} & $\mathrm{V}_{\mathrm{EP}}\left[\mathrm{dm}^{3}\right]$ & $\rho_{0}\left[\mathrm{~kg} \cdot \mathrm{dm}^{-3}\right]$ \\
\hline \hline 1 & SB-520 & 0.202 & & & 1.029 \\
\hline 2 & SB-412 & 0.100 & & & 0.509 \\
\hline 3 & DSB-20 & 0.198 & \multirow{2}{*}{100} & \multirow{2}{*}{0.196} & 1.008 \\
\hline 4 & DSB-15 & 0.197 & & & 1.003 \\
\hline 5 & DSB-10 & 0.198 & & & 1.008 \\
\hline 6 & SB-520 & 0.367 & & & 1.009 \\
\hline 7 & SB-412 & 0.176 & & & 0.486 \\
\hline 8 & DSB-20 & 0.359 & \multirow{2}{*}{185} & 0.363 & 0.989 \\
\hline 9 & DSB-15 & 0.359 & & & 0.989 \\
\hline 10 & DSB-10 & 0.359 & & & 0.989 \\
\hline
\end{tabular}

FOH was made of low-density polyethylene. FOH has one central position and 15 symmetrical positions for fibre optic cables at 5 different distances from the FOH centre (Fig.3). Since FOH in this research had same $50 \mathrm{~mm}$ diameter as explosive charges, fibre optic positions $y$ were 4.5, 9.0, 13.5, 18.0 and $22.5 \mathrm{~mm}$ from the central position. All distances were measured with $0.1 \mathrm{~mm}$ precision. Fibre optic cable ends were equally longitudinally positioned inside $\mathrm{FOH}$ and covered with thin aluminium foil to prevent premature transmission of light.
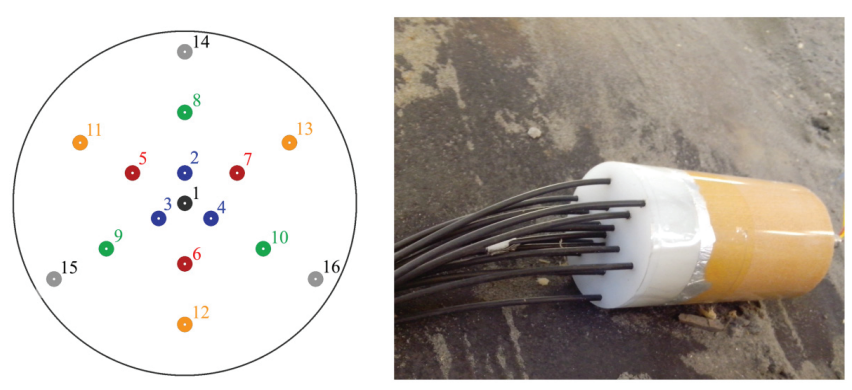

Figure 3. Positions of measuring points inside fibre optic holder 
Such arrangement of measuring points (MP) in $\mathrm{FOH}$ provides three records per same distance from the central position (MP 1).

Opposite ends of fibre optic cables were connected to the multi-channel fibre optic signal detector, connected to the Tektronix Mixed Signal Oscilloscope MSO 2022B, which served as a time counter. Oscilloscope has $200 \mathrm{MHz}$ bandwidth, $1 \mathrm{GS} / \mathrm{s}$ sampling and main maximum sample rate up to $2 \mathrm{~ns}$ in all 16 digital channels, so the device can measure time with $5 \mathrm{~ns}$ precision [9]. When DW arrives to a MP, light is transmitted through fibre optic cable to an optical detector, where it is transformed into electrical signal and then detected by the oscilloscope.

When properly protected, damage of fibre optic cables after each experiment was acceptably small. In each experiment, the cables were damaged up to $20 \mathrm{~cm}$ in length, and were reused in following experiments after proper inspection and equal shortening, in order to obtain same length of all cables and to minimize measuring errors.

\section{Analysis and discussion}

Experimental recordings were used to determine positions of points that correspond to DW front. It was necessary to reset all recordings according to the initial moment of time, when DW arrived at FOH. Initial moments were calculated as an average value of recordings at MP 1-4, in order to minimize errors due to non-ideal positioning of $\mathrm{FOH}$ and EDC and other experimental errors. Differences between recordings at MP 1-16 and initial moment represent time intervals $t_{1}-t_{16}$. After that, average values of time intervals $t_{\mathrm{sr}}$ were calculated for three MPs at same distances from MP 1 Average values $t_{\mathrm{sr}}$ were used to calculate the positions $x_{\mathrm{sr}}$ of DW at $y$ distances from MP 1 :

$$
x_{s r}=D_{L} \cdot t_{s r}
$$

$D_{L}$ is detonation velocity for EM at distance $L$ from the initiation point. Those values were previously experimentally determined [10]. It was also shown that $D_{\mathrm{L}}$ values are nearly constant at considered distances from initiation point. Nearly ideal constant values were observed at distances larger than $150 \mathrm{~mm}$.

Shape of DW can be approximated as spherical with radius $r_{D T}$.

$$
r_{D T}=\sqrt{x^{2}+y^{2}}
$$

Regression analysis was used to determine radii of DW according to calculated positions of points (Eq.2), for maximum $R^{2}$ criterion. The results are listed in Table 4.

Determined $x_{s r}$ values are not significantly distant from their presumed position. For example, for all charges at measuring points 2-4 values $x_{s r}$ of approximately $0.1 \mathrm{~mm}$ are expected (nearly planar DW). But, determined values are slightly different, up to $0.3 \mathrm{~mm}$. Similar is observed for other measuring points. This can be the consequence of experimental errors and can be considered acceptable.

Correlation of determined results is acceptable, where charges 2 and 8 have correlation lower than 0.90. Shape of DW for charges 2 and 7, filled with SB-412 is graphically represented in Fig. 4.

\begin{tabular}{|c|c|c|c|c|c|c|c|c|c|c|}
\hline \multirow{3}{*}{$\begin{array}{c}\text { Charge } \\
\text { No. }\end{array}$} & \multirow{2}{*}{ 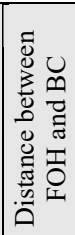 } & \multirow{2}{*}{ 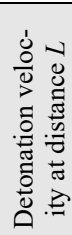 } & \multicolumn{6}{|c|}{ Average position of DW } & \multirow[b]{2}{*}{ 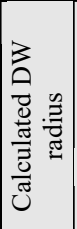 } & \multirow{3}{*}{$R^{2}$} \\
\hline & & & $\bar{\xi}$ & $\begin{array}{l}\stackrel{+}{~} \\
\stackrel{\text { ¿ }}{\Sigma}\end{array}$ & $\begin{array}{l}\hat{1} \\
\hat{n}\end{array}$ & $\begin{array}{l}\frac{0}{1} \\
\infty \\
\dot{\Sigma}\end{array}$ & $\begin{array}{l}\frac{m}{I} \\
\frac{\Xi}{\Sigma}\end{array}$ & $\begin{array}{l}\frac{0}{7} \\
\dot{I} \\
\stackrel{b}{\Sigma}\end{array}$ & & \\
\hline & $L, \mathrm{~mm}$ & $\begin{array}{l}D_{\mathrm{L}}, \\
\mathrm{ms}^{-1}\end{array}$ & \multicolumn{6}{|c|}{$x_{s r}, \mathrm{~mm}$} & $\begin{array}{l}r_{D T} \\
\mathrm{~mm}\end{array}$ & \\
\hline 1 & \multirow{5}{*}{90} & 5032 & 0.0 & 0.0 & 0.2 & 0.8 & 1.6 & 2.8 & 95.5 & 0.9916 \\
\hline 2 & & 3262 & 0.3 & -0.1 & 0.8 & 0.4 & 1.4 & 2.1 & 94.5 & 0.8824 \\
\hline 3 & & 5183 & 0.1 & 0.0 & 0.5 & 1.0 & 1.8 & 3.2 & 84.2 & 0.9909 \\
\hline 4 & & 4929 & 0.0 & 0.0 & 0.4 & 0.9 & 1.9 & 3.0 & 85.1 & 0.9965 \\
\hline 5 & & 4856 & 0.1 & 0.0 & 0.3 & 0.8 & 1.5 & 2.6 & 93.8 & 0.9940 \\
\hline 6 & \multirow{5}{*}{175} & 5203 & -0.1 & 0.0 & 0.4 & 1.5 & 1.5 & 4.8 & 63.8 & 0.9100 \\
\hline 7 & & 3459 & -0.1 & 0.0 & 0.4 & 1.2 & 2.2 & 3.8 & 71.0 & 0.9982 \\
\hline 8 & & 5185 & 0.0 & 0.0 & -0.1 & 0.7 & 0.9 & 5.0 & 69.2 & 0.8126 \\
\hline 9 & & 5169 & 0.1 & 0.0 & 0.1 & 0.4 & 0.0 & 1.9 & 122.3 & 0.9335 \\
\hline 10 & & 4952 & 0.0 & 0.0 & 0.2 & 0.8 & 1.5 & 2.6 & 86.2 & 0.9901 \\
\hline
\end{tabular}

Table 4. Results of experimental data analysis
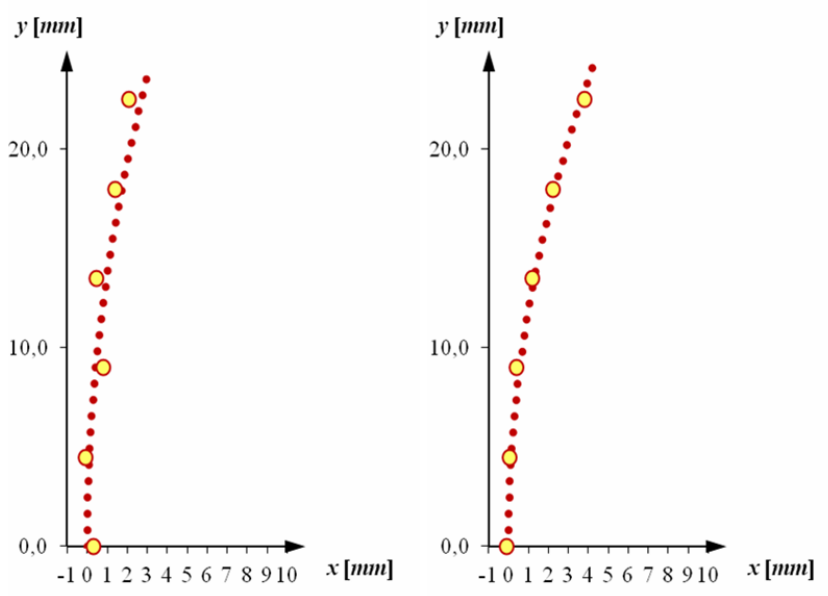

Figure 4. Shape of DW for charges number 2 and 7, filled with SB-412

\section{Conclusions}

Results show that DW curvature is in 84.2-95.5 mm range for all charges at $90 \mathrm{~mm}$ from initiation point. It can be concluded that radial propagation of DW is dominant. But, results show that change in DW curvature is occurring in all charges.

At $175 \mathrm{~mm}$ distance from initiation point, DW radii are in 63.8-86.2 $\mathrm{mm}$ range for all charges except DSB-15 $(122.3 \mathrm{~mm})$. It can be concluded that these values of $r_{D T}$ represent DW curvature in a stationary state of the system.

Assumption of spherical DW shape was considered because of its simplicity and it can be considered acceptable. Other curves could provide better correlation with experimental results.

Results of DW curvature are similar with results [11] for similar EM, but ultra high-speed camera was used. Method and measuring system used in this research are considerably more cost-effective compared to methods with ultra highspeed cameras. Charge preparation is moderately demanding in this method. 


\section{Acknowledgement}

The authors thank to the Department for Defense Technologies (UOT) Ministry of Defense of the Republic of Serbia for the help and support to this research.

\section{References}

[1] ОРЛЕНКО,Л.И.: (под редакцией): Физика взрыва, том 1., изд. 3., Наука, Москва, 2004, ISBN 5-9221-0219-2.

[2] ДРЁМИН,А.Н., САВРОВ,С.Д., ТРОФИМОВ,В.С., ШВЕДОВ,К.:: Детонационные волны в конденсированных средах, Наука, 1970.

[3] МИХАЙЛЮК,К.М., ТРОФИМОВ,В.С.: газодинамическом пределе распространения стационарной детонаиии, Физика горения и взрыва, 1977, Vol.13, No.4, pp. 606-613.

[4] MADER,C.L.: Numerical modeling of explosives and propellants, $2^{\text {nd }}$ ed., CRC Press LLC, Boca Raton, Florida, 1998, ISBN 0-8493-3149-8.

[5] BDZIL,J.B., STEWART,D.S.: Modelling two-dimensional detonations with detonation shock dynamics, Phys.Fluids, 1989, A.1, pp.12611267.
[6] SHARPE,G.J., BRAITHWAITE,M.: Steady non-ideal detonations in cylindrical sticks of explosives, J.Eng.Math. 2005, Vol.53, pp.39-58.

[7] WOOD,W.W., KIRKWOOD,J.G.: Diameter effect in condensed explosives. The relation between velocity and radius of curvature of the detonation wave, J. Chem. Phys., 1954 Vol.22, No.11, pp.1920-1924.

[8] Reports on physical and chemical characteristics of propellants, No.5, 55, 6883, 6853, Chemical Industry "MBL", Lučani, Republic of Serbia,.2015-03-25.

[9] Tektronix MSO2000B Series, DPO2000B Series Datasheet, (3GW28413-8), www.tek.com, 2018.

[10] BOGDANOV,J.: Prilog istraživanju procesa detonacije sferičnih baruta, doktorska disertacija, Vojna akademija, Beograd, 2016.

[11] DIMITRIJEVIĆ,R.: Istraživanje procesa detonacije pogonskih eksplozivnih materija, doktorska disertacija, Vojna akademija, Beograd, 2006.

\title{
Oblik detonacionog talasa u različitim eksplozivnim materijama sa nitrocelulozom i nitroglicerinom
}

\begin{abstract}
Izvršeno je eksperimentalno istraživanje oblika detonacionog talasa u cilindričnim eksplozivnim punjenjima sa 5 različitih eksplozivnih materija, u čijem sastavu su nitroceluloza i nitroglicerin. Razmatrane eksplozivne materije izrađene su tehnologijom proizvodnje sferičnih baruta. Oblik detonacionog talasa određen je metodom merenja vremena nailaska detonacionog talasa u određenu tačku u punjenju. Korišćen je merni sistem razvijen u Vojnotehničkom institutu u Beogradu sa 16 optičkih kablova, višekanalnim detektorom optičkog signala i osciloskopom. Zakrivljenost detonacionog talasa merena je na dva različita odstojanja od mesta iniciranja. Prosečne vrednosti poluprečnika detonacionog talasa određene su regresionom analizom eksperimentalno dobijenih podataka. Uočena je promena u zakrivljenosti detonacionog talasa na različitim odstojanjima od mesta iniciranja.
\end{abstract}

Ključne reči: detonacioni talas, eksplozivna materija, nitroceluloza, nitroglicerin. 